\title{
Hydrogen Economy and the Built Environment
}

\author{
S. El Azzeh ${ }^{1}$, M. Sarshar2 ${ }^{*}$ R. Fayaz ${ }^{3}$ \\ ${ }^{1}$ Liverpool John MooresUniversity, Liverpool, UK \\ ${ }^{2}$ Institute of Energy and Sustainable Development,De Montfort University, Leicester, UK \\ ${ }^{3}$ Art University, Karaj, Iran \\ * Marjan Sarshar Tel: +44 116257 7961, Fax: +44 116257 7977, E-mail:msarshar@dmu.ac.uk
}

\begin{abstract}
The hydrogen economy is a proposition for the distribution of energy by using hydrogen, in order to potentially eliminate carbon emissions and end our reliance on fossil fuels. Some futuristic forecasters view the hydrogen economy as the ultimate carbon free economy. Hydrogen operated vehicles are on trial in many countries. The use of hydrogen as an energy source for buildings is in its infancy, but research and development is evolving. Hydrogen is generally fed into devices called fuel cells, to produce energy.

A fuel cell is an electrochemical device that produces electricity and heat from a fuel (often hydrogen) and oxygen. Fuel cells have a number of advantages over other technologies for power generation. When fed with clean hydrogen, they have the potential to use less fuel than competing technologies and to emit no pollution (the only bi-product being water).

However, hydrogen has to be produced and stored in the first instance. It is possible to generate hydrogen from renewable sources, but the technology is still immature and the transformation is wasteful. The creation of a clean hydrogen production and distribution economy, at a global level is very costly.

Proponents of a world-scale hydrogen economy argue that hydrogen can be an environmentally cleaner source of energy to end-users, particularly in transportation applications, without release of pollutants (such as particulate matter) or greenhouse gases at the point of end use. Critics of a hydrogen economy argue that for many planned applications of hydrogen, direct use of electricity, or production of liquid synthetic fuels from locally-produced hydrogen and CO2 (e.g. methanol economy), might accomplish many of the same net goals of a hydrogen economy while requiring only a small fraction of the investment in new infrastructure.

This paper reviews the hydrogen economy, how it is produced, and distributed. It then investigates the different types of fuel cells and identifies which types are relevant to the built environment, both in residential and nonresidential sections. It concludes by examining what are the future plans in terms of implementing fuel cells in the built environment, and discussing some of the needs of built environment sector.
\end{abstract}

Keywords: Hydrogen, Fuel cells, Hydrogen economy, PEM Fuel Cells

\section{Introduction- Hydrogen}

\subsection{The Hydrogen economy}

A "Hydrogen Economy" is proposed as an ultimate solution for clean energy and the environment. Hydrogen communities have been formed for the promotion of this goal. They produce publications and organise meetings and exhibitions. The excitement is mainly about having a carbon free world. Electricity is considered one of the main $\mathrm{CO} 2$ emission sources relying on burning fossil fuels. A change in the production sources of energy is essential. Hydrogen is seen as a potential electricity carrier which is $100 \%$ clean and natural, but the challenge remains in its production, storage and distribution processes. Hydrogen is not found on its own in the globe, so it needs to be extracted from other elements that contain it. A key question is: is mass production of hydrogen physically possible? Similarly one needs to pose the question of: are the costs of producing, storing and distributing hydrogen affordable?

Hydrogen is not a natural fuel, but a synthetic energy carrier. It only carries energy generated by other processes. For example, hydrogen may be produced from electricity by electrolysis of water. In addition, high-grade electrical energy is also required to compress or liquefy it, and to transport, transfer, and store it [1]. Without question, the technology for a hydrogen economy exists or can be developed. In fact, vast amounts of hydrogen are generated, 
handled, transported and used in the chemical industry today. But this hydrogen is used as a chemical substance, not an energy source. Hydrogen production and transportation costs are absorbed in the price of the synthesized chemicals. The cost of hydrogen remains irrelevant as long as the final products find markets. However, today's debate for the use of hydrogen as an energy source is governed by economic arguments and not merely theoretical considerations.

In the academic literature, the production and the use of hydrogen have attracted significant attention, while the practical aspects of a hydrogen economy are rarely addressed. Fig. 1 below shows that like any other product, hydrogen must be packaged, transported, stored, and transferred to bring it from production to final use. These common market processes require energy [1]. Can we justify the transition to a hydrogen economy, based on practical and financial considerations? Some authors believe not!

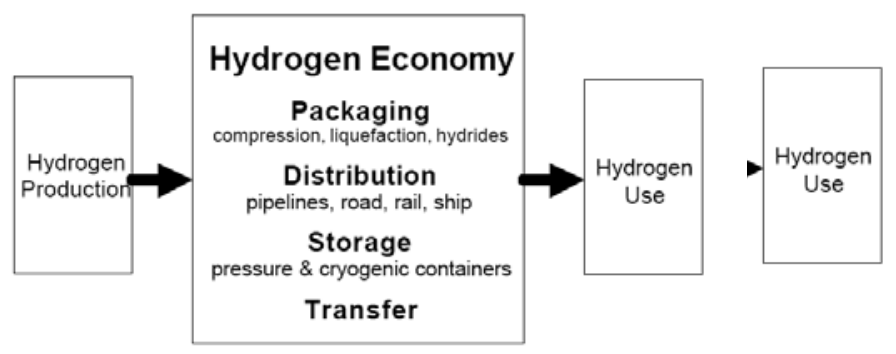

Figure 1: Schematic Representation of an elemental "Hydrogen Economy [1]

On the other hand, some scientists argue that novel energies need long, and sometimes very long periods of time; typically many decades to find their way onto the market. It may require up to half a century in order to establish of a novel energy regime in an irrevocable fashion. Hydrogen is no different. It is the right time to start the implementation of the hydrogen energy economy and see it through [2]. Winter [2] argues that Hydrogen is on track, because sustainable energy without the hydrogen economy is difficult to achieve, although there are still many milestones ahead.

Currently one needs to increase awareness amongst professionals and scientists around new technologies so that further development into realistic solutions becomes possible. "It takes about 50 years for a new idea to break through and become vogue; no one likes an intruder, particularly when he is upsetting the commonplace"[2].This paper provides some background to the hydrogen economy.

\subsection{Sources of Hydrogen}

Dunn [3] pointed that Hydrogen is hard to find on Earth as a separate element. Instead, it is primarily found in combination with oxygen in water, in combination with carbon in a range of hydrocarbon fuels, and in combination with carbon in plants, animals, and other forms of life. Once it is extracted, this colourless, odourless, and tasteless element becomes a useful "feedstock", or input, to a variety of industrial activities and a potentially ubiquitous fuel sufficient to energize virtually all aspects of society, from homes to electric utilities to business and industry to transportation. Therefore, hydrogen production means extracting and isolating hydrogen in the form of independent molecules, at the level of purity required for a given application [4]. 
Hydrogen is not widely used today in the Built environment sector, but has been tested on vehicles as exemplars and showcases. Winter [2] stated three main sources of Hydrogen, mentioning some of each source requirements and obstacles. He stated that Hydrogen can be produced from fossil fuels, renewable sources, or nuclear fission. (1) From fossil fuels via reformation or partial oxidation or gasification, preferably from natural gas, like today, or from coal, in the future, with capture and sequestration of coproduced carbon dioxide in order to prevent its release into the atmosphere. (2) From renewable electricity via electrolysis, but not before a number of further decades of development and in competition with the direct use of renewable electricity in the power market; or (3) From nuclear fission, if society accepts it.

Hydrogen production systems using renewable energy sources have been developed mostly in the United States (US) [5]. Example of that is the Telonicher Marine Lab in Trindad, California where they have installed the first solar hydrogen-Fuel cell system. The three major renewable hydrogen projects that have been completed in Europe are the Utsira hydrogen project, launched in July 2004 in Norway, the HARI project at West Beacon Farm, Leicestershire, UK, and PURE project in Unst (Shetland), opened in May 2005.

According to the DTI report Meeting, The Energy Challenge [6], Hydrogen and fuel cells are linked technologies with significant carbon-saving potential where the hydrogen is produced from renewable or low carbon sources. Furthermore, Hydrogen would facilitate the shift from limited non-renewable stocks of fossil fuels to unlimited flows of renewable sources, playing an important role in reducing and eliminating Carbon dioxide (decarbonisation) in the global energy system needed to avoid the most severe effects of climate change. Replacement of oil and other fossil fuels with hydrogen would achieve reductions in carbon emissions and avoid a doubling of pre-industrial carbon dioxide $\left(\mathrm{CO}_{2}\right)$ concentrations in the atmosphere [3].

Total's company publication [7] on hydrogen and fuel cells indicates that hydrogen can be produced through two broad process technologies:

1. By reforming or gasification of fossil fuels (e.g., natural gas, petroleum, coal) or products derived from the biomass (e.g., ethanol);

2. Alternatively, by electrolysis of water (using electricity generated by nuclear, wind, solar or other power).

According to Pant and Gupta [8], the current global hydrogen production is $48 \%$ from natural gas, $30 \%$ from petroleum, $18 \%$ from coal, and $4 \%$ from electrolysis.

\subsection{Hydrogen Production in Reality}

Hydrogen is a fascinating energy carrier. It can be produced from electricity and water. Its conversion to heat or power is simple and clean. Hydrogen forms water when combusted with oxygen. No pollutants are generated or emitted. The water is then returned to nature where it originally came from. But hydrogen, the most common chemical element on the planet, does not exist in nature in its pure form.

Hydrogen has to be separated from chemical compounds by electrolysis from water or by chemical processes from hydrocarbons or other hydrogen carriers. The electricity for the electrolysis may eventually come from clean renewable sources such as solar radiation, kinetic energy of wind and water or geothermal heat. Therefore, hydrogen may become an important link between renewable physical energy and chemical energy carriers [1]. 
Hydrogen is considered the "forever fuel", since, like electricity, it can be produced from any primary energy fuel: coal, oil, natural gas, nuclear, all sorts of renewable energies, and from grid electricity. Certainly, because of its environmental and climatic cleanness, hydrogen made from renewable energies is the ultimate aspiration. This is, however, not a pre-requisite for building a hydrogen energy economy.

Dunn [3], stated that about $99 \%$ of the hydrogen produced today comes from fossil fuels. Over the long run, this proportion needs to be shifted towards renewable sources, for hydrogen production to be sustainable. Hydrogen, produced from renewable energy (e.g., Solar) sources, would result in a permanent energy system, which will not need to be changed [9].

Bossel [10] believes that electrolysis may be the only practical link between renewable energy and hydrogen. Although solar or nuclear heat can also be used for high-temperature cyclic processes, it is unlikely that a recognisable fraction of the global energy demand can be served with hydrogen from solar concentrators or high-temperature reactors. Local wind farms are likely to deliver energy at lower costs than distant solar or nuclear installations.

Winter [2] argues that the future of electrolytic hydrogen depends clearly on the price of electricity. If the price of the electrolysis process for the production of hydrogen is high, the production will become harder, and vice versa. He notes that in all likelihood the future average electricity price will increase rather than decrease (at least in industrialized countries), electrolytic hydrogen may get its market only where the electricity demand is temporarily low, e.g., at night, or where base load (nuclear) power station has been underused.

A case study by Bossel in 2006 [10] finds interesting questions and indicates major challenges. He states that if about 50 jumbo jets leave Frankfurt Airport every day, each loaded with 130 tons of kerosene, to replace the energy by hydrogen, 50 tons of liquid hydrogen are needed per plane. The daily needs would be 2500 tons or $36000 \mathrm{~m} 3$ of the cryogenic liquid, enough to fill 18 Olympic-size swimming pools. Every day 22500 tons of water would have to be electrolyzed. The continuous output of eight 1-GW power plants would be required for electrolysis, liquefaction, and transport of hydrogen. If all 50 planes leaving the airport were converted to hydrogen, the entire water consumption of Frankfurt and the output of 25 full-size power plants would be needed to meet the hydrogen demand of air planes leaving just one airport in Germany. This case study demonstrates that the hydrogen economy is not a panacea and more effort in understanding the cost and the effort is required.

This doesn't prove that hydrogen is not the ideal solution. It does indicate that electrolysis (depending on water and electricity) is not the right solution at least for now, and an alternative should be studied before rising the issue of producing hydrogen from renewable sources. This indicates that current studies could be seen as misleading, from the point of view that they are just seeing and arguing about the benefits of using hydrogen for energy generating, which is true. Yet, more studies about the real life possible applications with all disadvantages must be considered as well. As mentioned before, the development and storage costs of hydrogen are to be explored before committing to using it.

\subsection{Storing and transporting Hydrogen}

Hydrogen seems to have some difficulties in storing and transporting. Some researchers have made remarkable points about this subject as hydrogen molecules are extremely tiny and will leak from almost any container or pipe, meaning that it needs to be liquefied at temperatures near absolute zero. Compressed hydrogen, at very best, would take up at least 4 times as much 
space in a tank as gasoline for the same amount of energy. Plus the storage tanks for compressed hydrogen cost 100 times the cost of a gas tank. Also, stronger materials, like steel, are more likely to react with hydrogen and become brittle. Combined with the high pressure, this makes the tanks susceptible to bursting [11].

Winter [2] added a few words on storage, he stated that: stationary hydrogen storage is at hand, both for gaseous and liquid hydrogen in high pressure steel flasks or cryogenic dewars*.

Large capacity underground storage for gaseous hydrogen in leached salt domes may build on what has been learned from operational underground air or natural gas storage, though special care needs to be taken to prevent leakage of the smallest element of the periodic table of elements: hydrogen! The most challenging venture is the tank onboard motor vehicles. For a usual vehicle range of, say, $500 \mathrm{~km}$, the tank for gaseous hydrogen requires an inner pressure of 700 bar, which from a manufacturing and lifelong safety standpoint, is not at all trivial to achieve and maintain.

\section{Fuel Cells}

\subsection{Main characteristics of Fuel Cells}

Stambouli and Traversa [12] stated that, a Fuel Cell is an energy conversion device that produces electricity by electrochemically combining fuel (hydrogen) and oxidant (oxygen from the air) gases through electrodes and across an ion conducting electrolyte. According to the DTI report, Meeting the Energy Challenge [6], the fuel cell does not run down or require any recharging; unlike a battery, it will produce energy as long as fuel is supplied. The battery is an energy storage device where all energy available is stored within the battery itself [13]. According to the European commission summary report [14], because of fuel cells' low noise and high power quality, fuel cells systems are ideal for use in hospitals or IT-centres, or for mobile applications.

Fuel cells generally have a heat to power ratio of roughly 1:1 with overall efficiencies of around $80 \%$ when fired on hydrogen. Fuel cells powered with pure hydrogen have potential power efficiencies of up to $45 \%$ i.e. $45 \%$ of the hydrogen is converted into electrical energy. However, when we add a reformer to convert other fuels to hydrogen, this can drop significantly [15].

Neef [16] argues that hydrogen and fuel cells are technologies that still need to prove their capability in order to produce marketable products.

Three application areas for fuel cells are emerging: (1) In portable electronics fuelled with the help of hydrogen or methanol cartridges (e.g. laptops and mobile phones) (2) in stationary applications, (e.g. buildings) and (3) in the transportation sector in busses, passenger and light duty vehicles, later in heavy duty trucks, in aviation and at sea [2].

*Dewar: a double-walled flask of metal or silvered glass with a vacuum between the walls, used to hold liquids at well below ambient temperature. 


\subsection{Fuel Cells types for buildings}

Stambouli and Traversa [12] explain that there are many types of fuel cells, which are normally sorted by either by their operating temperature or by their classification. The latter is generally done according to the nature of electrolyte. The basic differences in the different types of fuel cells are:

- The electrolytes used;

- The operating temperature of the device;

- The design, and their fields of applications, bearing in mind that each fuel cell type has specific fuel requirements [17].

Operating temperatures of fuel cells vary depending on their type. There are two main categories for classification:

Firstly, the low temperature fuel cells with operating temperatures as low as $80^{\circ} \mathrm{C}$. These can be installed in private households, light commercial operations, and large industrial operations. An examples of this type is the Proton exchange membrane fuel cell (PAFC). In low-temperature fuel cells, all the fuel must be converted to hydrogen prior to entering the fuel cell.

Secondly, the high temperature fuel cells, such as molten carbonate (MCFC) and solid oxide (SOFC), may be adapted for larger industrial applications. With operating temperatures between $600-1100^{\circ} \mathrm{C}$ these high temperature cells can tolerate a contaminated source of hydrogen and hence can use unreformed natural gas, diesel or gasoline. Furthermore, the heat generated can be used to produce electricity by driving steam turbines.

Fuel cells in the stationary sector, i.e. for residential energy and for industrial application, will use different fuels and convert them into hydrogen as long as there is no hydrogen infrastructure in place. In the case of low temperature fuel cells, a reformer is used that converts natural gas into hydrogen and $\mathrm{CO} 2$, for example. High temperature fuel cells can convert the fuel, e.g. biogas, internally. Once again, the advantages of such stationary fuel cell systems compared to the competing condensing boilers or conventional heat and power plants consist of higher efficiencies and reduced emissions, but also of a contribution to the decentralised electricity production and to stability of the electric grid [16].

The most common fuel cells types found in the literature today and suitable for buildings are:

- Proton Electrolyte Membrane Fuel Cells (PEMF C),

- Alkaline Fuel Cells (AFC),

- Phosphoric Acid Fuel Cells (PAFC),

- Molten Carbonate Fuel Cells (MCFC) and

- Solid Oxide Fuel Cells (SOFC)

listed in the ascending order of their operating temperature, where the most electrical efficient of them is found to be the SOFC which has a high operating temperature. Lipman et al., [18], explain that low temperature PEM fuel cells are considered the leading contenders for automotive and small stationary applications. SOFC, PAFC, and MCFC operate at higher temperatures (from 2001C to 10001C) and are expected to be used for larger stationary applications. Regarding efficiency, generally fuel cells have high efficiency, where they convert up to $50-70 \%$ of available fuel to electricity (90\% with heat recovery ) [12]. 
Winter [2] stated that depending on the type of fuel cell, it provides the right temperature for heat applications in stationary use: $100 \mathrm{C}$ for proton exchange membrane (PEM) fuel cells (FCs), around $200 \mathrm{C}$ for high-temperature PEMs or phosphoric acid FCs (PAFCs), 600-650 _C for molten carbonate FCs (MCFCs), and 700-900_C for solid oxide fuel cells (SOFCs).

Low to high temperature PEMs are exactly what is needed for homes or buildings or hospitals, depending under which climate and weather conditions they serve; MCFCs fit the exigencies of many small-to-medium size industries, hospitals and large laboratories, and SOFCs are an excellent topping technology for gas turbine/steam turbine combined cycles [2].

But to be more precise the types we are concerned with in this project, are the types that rely on hydrogen only as their fuel, and from the existing applications. Table 1 below shows that PEM and PAFC are the two fuel cells types that could generate electricity for buildings with the use of hydrogen as their fuel. According to Lidderdale and Jones [15] PAFC type is the most successful technology, in terms of numbers deployed above $200 \mathrm{kWe}$, where it is used primarily for large back-up and remote power applications in hospitals, schools, and other locations where an engine generator would traditionally be used. Increasingly being used in environments where high availability of either electrical or thermal power is a criterion.

\begin{tabular}{|c|c|c|c|c|c|c|}
\hline $\mathrm{T} \rightarrow$ & & & & & & \multirow{7}{*}{$\begin{array}{l}\text { DMFC } \\
\text { Direct Methanol FC } \\
\text { PEMFC } \\
\text { Proton Exchange } \\
\text { Membrane FC } \\
\text { PAFC } \\
\text { Phosphor Acid FC } \\
\text { MCFC } \\
\text { Molten Carbonate FC } \\
\text { SOFC } \\
\text { Solid Oxide FC }\end{array}$} \\
\hline & DMFC & PEMFC & PAFC & MCFC & SOFC & \\
\hline Electrolyte & $\begin{array}{l}\text { Proton } \\
\text { conducting } \\
\text { membrane }\end{array}$ & $\begin{array}{l}\text { Proton } \\
\text { conducting } \\
\text { membrane }\end{array}$ & $\begin{array}{l}\text { Phosphoric } \\
\text { acid }\end{array}$ & $\begin{array}{l}\text { Molten } \\
\text { carbonate }\end{array}$ & Ceramic & \\
\hline $\begin{array}{l}\text { Temperature } \\
\text { Range }\left({ }^{\circ} \mathrm{C}\right)\end{array}$ & $<100$ & $<100$ & ca. 200 & ca. 650 & $800-1000$ & \\
\hline Fuel & methanol & hydrogen & hydrogen & $\begin{array}{l}\text { Natural gas, } \\
\text { coal gas, } \\
\text { biogas }\end{array}$ & $\begin{array}{l}\text { Natural gas, } \\
\text { coal gas, } \\
\text { biogas }\end{array}$ & \\
\hline $\begin{array}{l}\text { Power } \\
\text { Range }\end{array}$ & $\mathrm{W} / \mathrm{kW}$ & $\mathrm{W} / \mathrm{kW}$ & $\mathrm{kW}$ & $\mathrm{kW} / \mathrm{MW}$ & $\mathrm{kW} / \mathrm{MW}$ & \\
\hline $\begin{array}{l}\text { Application } \\
\text { (examples) }\end{array}$ & $\begin{array}{l}\text { Vchicles, } \\
\text { portables }\end{array}$ & $\begin{array}{l}\text { Vehicles, } \\
\text { house } \\
\text { encrgy, } \\
\text { CHP }\end{array}$ & CHP & $\begin{array}{l}\text { Power } \\
\text { plants }\end{array}$ & $\begin{array}{l}\text { House } \\
\text { cnergy, } \\
\text { Power } \\
\text { plants }\end{array}$ & \\
\hline
\end{tabular}

Table 1: fuel cells types and main characteristics [16]

Realistically speaking and because the technology (Fuel cells) is still newly introduced to the built environment, a definite answer about the most appropriate type for buildings cannot be stated yet, it will take several years and many real life pilots to proove what is and what is not suitable for buildings.

\subsection{Future plans for Fuel Cells implementations}

Winter [2] stated that like any other energy, hydrogen energy has to meet a range of criteria before successfully entering the market. The two major, perhaps dominating criteria are costs and $\mathrm{CO} 2$ emissions. Of course, costs are the key for the entry of any energy into a competitive large scale market, and hydrogen energy is not different.

Same is applicable for fuel cells technology; cost, reliability and lack of experience are the major issues. To resolve these problems and to answer all unclear questions, implementing the technology in several projects is a necessity and this should be supported by the government and large private energy companies as a start, because like any other technology the cost of it at present is considerably high which makes it hard for the end users to even consider installing such technology in their houses or projects, especially that sustainable and clean hydrogen sources are not readily available as yet. Therefore, support is required at this stage to implement the technology for a small community and learn from the experiences. 
According the Fuel cells handbook 2004 [13], for a fuel cell to compete with other generation sources, its price must be reduced dramatically and research and development is required to improve the performance and reduce the cost of renewables, storage, and fuel cell technologies. Technologies are needed that can produce hydrogen for the same price as gasoline. Storage technologies must be developed to allow cheap, safe hydrogen storage. Finally, fuel cell technology must advance to improve efficiency.

In addition, Safety is seen as a prime consideration for stationary fuel cells. As fuel cells come closer to the customer, codes must be written and building inspectors educated to allow the introduction of fuel cell power systems.

Another interesting point to be taken care of for moving forward with fuel cells technologies is obtaining insurance for hydrogen projects. This needs to be undertaken by the government to provide a layer of insurance coverage. In addition, insurance companies must be educated as to the proper handling of hydrogen and the associated risks. This would allow for property, liability, and efficacy insurance to be offered at reasonable rates.

\section{Future directions and future research needs}

Renewbles are one of the few rapidly growing business sectors, and developers are working hard to forge a link between renewable and fuel cell technology in order to put power generation on a sustainable basis. In the next five to ten years biogas fuel cells are supposed to operate worldwide, and active research will take place on wood and biomass gasifiers for hydrogen production. Wind power will be used to generate hydrogen in some locations, while solar hydrogen will be produced in others to power a small fleet vehicles [19].

The fuel cell industry itself is in its infancy. The early products have problems with reliability and affordability. It is as yet unclear which types of fuel cells will prove more appropriate for the different types of buildings and usage. Early piloting of the technology must be facilitated by government organisations and major corporations.

The construction industry is still not prepared for the introduction and maintenance of such eventual novel technologies. The design, implementation, and maintenance of them require specialist knowledge, which is still non-existent within the industry.

Future research needs to be collaborative, including stakeholders from the construction industry, the energy sector and the fuel cell technology sector (i.e. chemical engineers). Possible research areas include:

- Potential solutions for hydrogen production on site;

- Hydrogen harvesting, i.e. the best sustainable source for hydrogen production with the least cost;

- A critical analysis of the different types of fuel cells for different building types;

- Hydrogen onsite storage mechanism;

- Legislative barriers and enablers. 


\section{References}

[1] Bossel U, Eliasson B (2003) Energy and the Hydrogen Economy,(available online http://www.methanol.org/pdfFrame.cfm?pdf=HydrogenEconomyReport2003.pdf [accessed on 20/08/2009])

[2] Winter C (2009) "Hydrogen energy d Abundant, efficient, clean: A debate over the energy-system-of-change”. International Journal of hydrogen energy 34:1-52

[3] Dunn S (2002) "Hydrogen futures: toward a sustainable energy system”. International Journal of Hydrogen Energy, 27, 235-264.

[4] Sorensen B (2005) "Hydrogen and Fuel Cells, Emerging technologies and applications, A volume in the "Sustainable World" series". ELSEVIER academic press. chapter 2, pages 5-110.

[5] Gazey R, Salman S, and Aklil-D'halluin D (2006) “A field application experience of integrating hydrogen with wind power in a remote island location”. Power sources 157: 841-847

[6] DTI report, Meeting the Energy Challenge (2007) Energy white paper HMG CM 7124. Published by the stationary office (TSO).

[7] Total company publication (2007) hydrogen and fuel cells, (available online http://www.total.com/en/corporate-social-responsibility/Publications/ [accessed on 15/12/2008])

[8] Pant K, and Gupta R, Edited by Gupta, R (2009) "Hydrogen fuel: production, transport, and storage" chapter 1: Fundamentals and Use of Hydrogen as a Fuel, Published by: Taylor \& Francis Group.

[9] Veziroglu T, and Sahin S (2008) “21st Century’s energy: Hydrogen energy system”. Energy conversion and management 49: 1820-1831.

[10]Bossel U (2006) “Does a Hydrogen Economy Make Sense?”. Proceedings of the IEEE 94: No. 10, 1826-1837

[11]Energy justice fact sheet: Hydrogen and fuel cells (2007) (available online http://www.energyjustice.net/ [accessed on 25/09/2008])

[12] Stambouli A, Traversa E (2002) “Fuel cells, an alternative to standard sources of energy". Renewable and Sustainable Energy Reviews 6: 297-306

[13]Fuel cell handbook (2004) seventh edition, by U.S.Department of Energy, office of fossil energy.(available online

http://www.brennstoffzellen.rwth-aachen.de/Links/FCHandbook7.pdf

[accessed on [1/1/2009])

[14]European Commission (2007) Combating climate change, The EU leads the way. (available online http://ec.europa.eu/publications/booklets/move/70/en.pdf [accessed on 10/04/2009])

[15]Lidderdale J, and Jones P (2006) "Fuel cells CHP for buildings", proceeding of the CIBSE (The Chartered Institution of Building Services Engineers) national conference. (available online http://www.cibse.org/index.cfm?go=page.view\&item=581[ accessed on 10/04/2009])

[16]Neef H (2009) “International overview of hydrogen and fuel cell research”.Energy 34: 327-333. 
[17]Ibrahim H, Ilinca A, Perron J (2008) "Energy storage systems-Characteristics and comparisons”. Renewable and Sustainable Energy Reviews 12: 1221-1250

[18]Lipman T, Edwards J, and Kammen D, (2004) "Fuel cell system economics: comparing the costs of generating power with stationary and motor vehicle PEM fuel cell systems". Energy Policy 32:101-125

[19] Fuel cell technology handbook (2002) edited by Gregor Hoogers, proceedings of the institution of mechanichal engineers, Automobile engineering 217: no.5. 